\title{
RISIKO DI BANK SYARIAH: SUATU PENGANTAR
}

\author{
Hendra Cipta \\ IAIN Syaikh Abdurrahman Siddik Bangka Belitung
}

\begin{abstract}
Islamic banks are banks whose products range from funding to financing. With more and more of these products, of course the risks faced by Islamic banks are also increasingly diverse. So, through this article will explain what risks are faced by conventional banking and Islamic banking. This article will also outline the risks faced by financing channeled by Islamic banks and how to implement risk management in Islamic banks to mitigate the risks they face.
\end{abstract}

Keywords: Financing Risk, Risk management, Islamic banking

\section{A. Pendahuluan}

Islam menganjurkan bagi umatnya melaksanakan aktivitas bisnis dan beribadah. ${ }^{1}$ Investasi merupakan salah satu bagian dari aktivitas bisnis yang memungkinkan munculnya risiko dan return di saat bersamaan maupun di saat yang berbeda. Investasi akan berhadapan dengan risiko, karena risiko tidak mungkin dihilangkan begitu saja. Jika ditelaah lebih jauh, investasi Islami adalah investasi yang banyak mengandung risiko. Karena ketika aktivitas investasi Islami ini dijalankan aktivitasnya banyak berhubungan dengan instrumen investasi yang berisiko tinggi. ${ }^{2}$

Peran bank syariah dalam hal perantara nasabah yang memerlukan bantuan dana dengan nasabah yang punya surplus dana tidak terlepas dari risiko-risiko $^{3}$ yang suatu saat bisa menimbulkan dampak negatif bagi

\footnotetext{
${ }^{1}$ Al-Qashash (28): 77.

${ }^{2}$ Karnaen Perwataatmadja dkk, Bank Dan Asuransi Islam di Indonesia, editor
} Wirdyaningsih (Jakarta: Kencana, 2005), hlm. 208.

${ }^{3}$ Muhammad, Dasar-dasar Keuangan Islami (Yogyakarta: Ekonisia, 2004), hlm. 106-109. 
perbankan pada produk funding nya dan pada produk financing nya (pembiayaan).

Dampak buruk dalam bentuk risiko yang dihadapi oleh perbankan syariah tersebut telah diantisipasi perbankan melalui penerapan manajemen risiko $^{4}$ sebagai bentuk kewaspadaan perbankan sebagaimana yang tertuang dalam Undang-undang Nomor 7 Tahun 1992 dan telah diganti dengan dengan beberapa penyesuaian melalui Undang-undang Nomor 10 Tahun 1998. Sementara itu bagi bank syariah, keharusan penertiban risiko ini diatur pada pasal 38-40 Undang-undang Nomor 21 Tahun 2008. ${ }^{5}$

Pesatnya perkembangan internal dan eksternal perbankan syariah berefek terhadap bertambahnya aneka ragam risiko yang mengarah kepada perbankan syariah. Dengan semakin kompleksnya risiko ini bank syariah harus dapat berinovasi dan menyesuaikan prinsip manajemen risiko berbasis nilainilai syariah. Islamic Financial Services Board (IFSB) telah mengeluarkan aturan baku tentang prinsip-prinsip manajemen risiko yang harus dipatuhi bank-bank syariah. Bank Indonesia menerapkan regulasi pengelolaan risiko bagi perbankan syariah berdasarkan pada ukuran, kompleksitas usaha, dan kemampuan perbankan. ${ }^{6}$

\section{B. Agency Problem}

Kata agensi bermakna mekanisme konduktif perusahaan bisnis diatur. Pada dasarnya, fungsi agensi diarahkan oleh modalitas kontrak. Biaya agensi adalah faktor yang terdapat pada masing-masing kontrak. Perbedaan

${ }^{4}$ Untuk menilai kesehatan dan kehandalan industri perbankan, informasi mengenai risiko dan bagaimana fluktuasi dikelola penting untuk dipertimbangkan sebagai salah satu indikator kesehatan industri perbankan. Anjum Iqbal, "Liquidity Risk Management: A Comparative Study between Conventional and Islamic Banks of Pakistan", Global Journal of Management and Business Research, Vol. 12, Edisi 5, versi 1.0, Maret 2012.

${ }^{5}$ Rachmadi Usman, Aspek Hukum Perbankan Syariah di Indonesia (Jakarta: Sinar Grafika, 2012), hlm. 304.

6 Bank Indonesia, Booklet Perbankan Indonesia 2012, hlm 105. 
kepentingan dan informasi asimetris antara pemilik saham dan agen dapat menyebabkan output bergantung pada sifat kompensasi kontrak. Perbedaan teori tentang agensi memperlihatkan hubungan antara remunerasi dan produktifitas yang menentukan perkembangan perusahaan dan perilaku agensi. ${ }^{7}$

Model-model principal-agent menganalisis situasi informasi yang tidak merata atau asimetris yang didapatkan oleh pihak-pihak yang mempunyai kepentingan berbeda-beda. Kebanyakan analisis diarahkan pada "hubungan" yaitu dimana satu pihak berbuat mewakili pihak yang lain sebagaimana yang terdapat pada kontrak kerja, agensi ataupun perjanjian francais. Adverse selection dan moral hazard timbul ketika pemilik saham tidak bisa mengwasi dan mengkaji tindakan yang dilakukan agen, dengan kondisi seperti ini maka muncullah problem agensi. ${ }^{8}$

Teori keagenan adalah teori yang mengatur interaksi bisnis antara pemegang saham dengan agen sebagai tangan kanan pemilik saham dalam sebuah perusahaan. Masalah keagenan muncul ketika pemegang saham yang menunjuk agensi membuat keputusan yang berkaitan dengan pemegang saham. Sebagaimana yang dikatakan Beth Arnold dan Paul de Lange ketika mengutip Jensen mengatakan bahwa keputusan yang mementingkan kepentingan sendiri akan menyebabkan konflik dengan kepentingan kooperatif.

Secara alamiah, kadang-kadang keputusan beberapa manager muncul karena motivasi mementingkan kepentingan sendiri yang dari sisi lain tentunya akan mengorbankan kepentingan (mengurangi kesejahteraan) para pemegang saham, dengan terjadinya konflik kepentigan ini kedua pihak akan merugi.

7 Md. Abdul Awwal Sarker, "Islamic Business Contracts, Agency Problem and The Theory of The Islamic Firm", International Journal of Islamic Financial Services, Vol. 1, No. 2, hlm. 8.

${ }^{8}$ Ibid., hlm. 8. 
Oleh karena itu, teori keagenan diharapkan bisa memberikan landasan bagi manajemen sebuah perusahaan.

Ketika informasi tidak lengkap dan munculnya ketidakpastian, maka menurut teori keagenan akan muncul dua masalah, yaitu : (1) Adverse selection, yaitu pemilik saham tidak dapat menilai apakah agensi yang dibayarnya sudah melakukan pekerjaan sesuai yang diinginkannya atau tidak. (2) Moral hazard, yaitu pemilik saham tidak yakin apakah agensi sudah melakukan pekerjaan sesuai dengan kemampuannya. Beth Arnold dan Paul de Lange ketika mengutip Jensen dan Meckling mengatakan bahwa mekanisme insentif dan pengawasan lebih baik dilakukan untuk menghadapi perilaku oportunisme dalam korelasi pemilik saham dan agensi. Perilaku oportunisme dalam teori keagenan diasumsikan sebagai perilaku untuk mengutamakan kepentingan pribadi.

Berdasarkan teori keagenan, informasi asimetris akan muncul ketika manajemen (agensi) lebih banyak mendapatkan informasi daripada pemilik saham. Padahal informasi tempat pemilik saham menanamkan investasinya sangat diperlukan oleh para pemegang saham. Hal ini mengakibatkan pemilik saham tidak dapat mengontrol tindakan yang dilakukan oleh agensi. ${ }^{9}$

Pada sudut pandang korpus keuangan, profit bagi bank syariah adalah kesanggupan mengelola risiko dengan maksimal pada pembagian return project antara pemodal dan pebisnis. Walaupun mekanisme dalam bantuk ini memberikan keutungan bagi perbankan syariah, ternyata profit and loss sharing perbankan syariah masih akan menghadapi beberapa masalah problem agensi dengan meningkatnya informasi asimetris dan biaya pemantauan. ${ }^{10}$

Abdus Samad dan M. Kabir Hasan sebagaimana dikutip Hendy Herianto mengatakan bahwa akad-akad yang ada di perbankan syariah

\footnotetext{
9 Beth Arnold dan Paul de Lange, "Enron: an Examination of Agency Problems", Critical Perspectives on Accounting, 2004, hlm. 753.

${ }^{10} \mathrm{Md}$. Abdul Awwal Sarker, International Journal ...., hlm. 9
} 
memerlukan keterbukaan informasi dan transparansi yang komprehensif karena pada akad-akad yang ada di bank syariah terdapat asymmetric information. Apabila terjadi pembiaran terus-menerus maka menyebabkan agency problem dan risiko yang akan dihadapi oleh perbankan syariah semakin kompleks.

Di sisi lain, bank syariah apabila tidak berhati-hati dan menerapkan manajemen risiko yang kompleks dalam memilih proyek yang akan diberikan pembiayaan, maka bank syariah akan menemui kendala adverse selection. Dalam memilih proyek yang akan dibiayai sebaiknya bank syariah jangan hanya melihat dari besarnya keuntungan yang akan diperoleh, tetapi harus diperhatikan juga besar dan kecilnya dampak buruk yang mengintai bank syariah terhadap pembiayaan yang digulirkan di suatu proyek. ${ }^{11}$

Agency problem adalah konsep dari incentive based contract, yaitu sistem kontrak yang menghargai pekerjanya dengan meningkatkan usaha dan produksi. Wujud penghargaan ini berbentuk profit sharing, profit-related-pay, dan bonus. ${ }^{12}$

\section{Risiko-Risiko yang Dihadapi Perbankan}

Kedudukan syariat pada struktur aset dan liabilitas bank Islam berbeda dari bank konvensional. Ini memperlihatkan beberapa keunikan risiko yang mengarah ke bank syariah. Maka, beberapa alat standar manajemen risiko seperti pasar (pemasaran) dan kredit tak orisinil, pertukaran (tukar-menukar) rata-rata bunga dan beberapa risiko yang menuju ke bank konvensional tidak sama dengan risiko yang mengarah ke bank syariah. Bank syariah mengembangkan beberapa alternatif yang sesuai dengan instrumen ini. Beberapa alat manajemen risiko tradisional dan proses-proses yang sama

\footnotetext{
${ }^{11}$ Hendy Herijanto, Selamatkan Perbankan Demi Perekonomian Indonesia (Jakarta: Expose PT Mizan Publika, 2013), hlm. 252.

12 Muhammad, Manajemen Pembiayaan Mudharabah di Bank Syariah (Jakarta: Rajawali, 2008), hlm. 67.
} 
mampu diaplikasikan pada bank Islam dalam bentuknya yang asli. Bagaimanapun, sejumlah alat-alat yang lain akan membutuhkan sebagaimana mestinya yang diadaptasi oleh pada syarat-syarat spesial pada bank Islam. ${ }^{13}$

Menurut Muhammad, setiap bisnis akan selalu berhadapan dengan risiko dan pendapat (risk-return). Termasuk dalam lingkungan bisnis tersebut adalah dunia perbankan, artinya perbankan pun juga akan menghadapi kemungkinan risk dan return dalam bisnisnya. Lebih jauh Muhammad mengatakan bahwa kemungkinan risiko-risiko yang "menghantui" perbankan tersebut adalah risiko likuiditas (liquidity risk), risiko kredit (credit risk), dan risiko tingkat bunga (interest rate risk). Di samping itu kita juga mengenal adanya risiko operasional (operational risk) dan risiko nilai tukar valuta asing (foreign exchange rate risk),. ${ }^{14}$ Selain risiko-risiko di atas Zainal Arifin menambahkan bahwa juga ada risiko modal (capital risk). 15

Bank Indonesia sangat serius dalam mengawasi risiko-risiko yang akan dihadapi perbankan. Bukti keseriusan Bank Indonesia ini diwujudkannya dengan membuat regulasi-regulasi tentang manajemen risiko yang harus diterapkan bagi dunia perbankan yang ada di Indonesia (meliputi syariah dan konvensional). Di antara aturan yang berasosiasi dengan manajemen risiko di perbankan ini adalah Peraturan Bank Indonesia (PBI) No. 5/8/PBI/2003 tanggal 19 Mei 2003 tentang "Penerapan Manajemen Risiko untuk Bank Umum. Regulasi ini kemudian dilengkapi lagi PBI No. 7/25/PBI/2005 pada Agustus 2005 tentang "Sertifikasi Manajemen Risiko bagi Pengurus dan Pejabat Bank Umum". Kedua regulasi di atas kemudian dilengkapi oleh Bank Indonesia dengan PBI No. 8/4/PBI/2006 yang disempurnakan melalui PBI No.

13 Syed Jaafar Aznan, Islamic Financial Industry: Risk Management, Regulation and Supervision, disampaikan pada disampaikan pada konferensi bank Islam internasional pada tahun 2003.

14 Muhammad, Manajemen Bank Syariah, edisi revisi (Yogyakarta: (UPP) AMP YKPN), 2005), hlm. 357-358.

15 Zainul Arifin, Dasar-dasar Manajemen Bank Syari'ah (Jakarta: Pustaka Alvabet, 2005), hlm. 60 . 
8/14/PBI/2006 perihal "Pelaksanaan Good Corporate Governance bagi Bank Umum". ${ }^{16}$

\section{Risiko Kredit (Credit Risk)}

Risiko kredit adalah keadaan bahaya yang akan mengarah ke perbankan ketika tidak mendapatkan cicilan pokok dan bunga pinjaman atas investasi pinjaman yang disalurkan ke nasabah yang meminjam dana ke bank tersebut (versi konvensional). ${ }^{17}$ Sedangkan di perbankan syariah risiko kredit ini dikenal dengan istilah risiko pembiayaan.

Risiko kredit ini akan muncul apabila bank tidak menerapkan prinsip prudent dalam melakukan investasi kredit atau terlalu mudah memberikan pinjaman karena tuntutan pemanfaatan kelebihan likuiditas, dengan tuntutan ini akhirnya perbankan "lalai" dalam mengantisipasi risiko-risiko yang akan dihadapinya pada kredit yang akan digulirkannya. Krisis dan resesi ekonomi adalah di antara faktor-faktor utama yang akan menyebabkan munculnya risiko ini (seperti yang terjadi pada krisis moneter 1997/1998 di Indonesia).

Penurunan pendapatan dari suatu perusahaan juga merupakan faktor yang akan menyebabkan kredit macet karena dengan berkurangnya pendapatan penghasilan perusahaan tersebut juga mengalami penurunan, sehingga dengan penurunan penghasilan ini perusahaan yang berposisi sebagai debitur suatu perbankan akan mengalami kesulitan untuk membayar hutanghutang kreditnya ke perbankan. Dan ketika perusahaan tersebut tidak mampu membayar kewajiban hutangnya, bunga pembayaran hutang tersebut terus mengalami peningkatan (bunga berlipat ganda) yang membuat perusahaan tersebut semakin sulit untuk melunasi kreditnya. Dan permasalahan

${ }^{16}$ Ferry N. Idroes, Manajemen Risiko Perbankan: Pemahaman Pendekatan 3 Pilar Kesepakatan Basel II Terkait Aplikasi Regulasi dan Pelaksanaannya di Indonesia (Jakarta: Rajawali Pers, 2008), hlm. 52.

17 Jhon Bitner dan Robert A. Goddard, Asset Liability Management: A Guide to The Future Beyond GAP, (New York: John Wiley dan Sons, 1992), hlm. 77 
berikutnya juga akan muncul ketika nilai nominal jaminan yang diagunkan perusahaan tersebut tak sepadan dengan nilai pinjaman yang disalurkan, sehingga saat bank akan mengambilalih jaminan tersebut (ketika pinjaman macet) bank tidak menerima pendapatan yang patut dari penjualan agunan tersebut. Semakin besar persentase kredit macet di suatu perbankan, maka perbankan tersebut sedang mengahadapi permasalah likuiditas yang akut.

Risiko kredit ini bisa diminimalisir dengan membatasi wewenang bagian perkreditan berlandaskan kompetensinya (authorize limit) dan limit kuantitas (pagu) penyaluran kredit (credit line limit) dan dengan diversifikasi. ${ }^{18}$ Risiko kredit akan mudah dikenali dengan menguji portofolio kredit. ${ }^{19}$ Diversifikasi macam-macam kredit, diversifikasi jenis-jenis industri yang akan diberikan kredit, kebijakan agunan dan lain-lain serta penerapan standar pengendalian kredit adalah faktor-faktor yang berpengaruh terhadap pengendalian risiko kredit perbankan. Sebagaimana teori dalam manajemen risiko semakin banyak profit yang diinginkan, maka semakin besar dampak bahaya yang menghadang, demikan juga dengan bisnis di dunia perbankan. ${ }^{20}$

\section{Risiko Likuiditas (Liquidity Risk)}

Likuiditas adalah kapabilitas perbankan mencukupi keperluan dananya dengan cepat dan dengan pengeluaran yang pantas, atau dengan kata lain kemampuan perbankan untuk mencairkan asetnya ke dana cash secepat mungkin. Ketersediaan cadangan likuiditas penting dilakukan perbankan untuk memenuhi kebutuhan dana mendesak nasabahnya yang tentunya akan berdampak pada kepuasan nasabah terhadap layanan perbankan.

18 Zainul Arifin, Dasar-Dasar Manajemen Bank Syariah, hlm. 210.

19 Portofolio merupakan surat-surat berharga keuangan. Dikutip dari Christopher Pass dan Bryan Lones, Collins Kamus Lengkap Ekonomi, edisi kedua, diterjemahkan oleh Tumpul Rumapea dan Posman Haloho (Jakarta: Erlangga, 1994), hlm. 493.

20 Ibid...., hlm. 61. 
Ketersediaan likuiditas sangat dibutuhkan perbankan karena berkaitan dengan kewajiban perbankan kepada nasabahnya, jika ada nasabah yang akan menarik dananya dan ada pula yang menarik fasilitas kreditnya, perbankan tentunya harus memiliki cadangan likuiditas yang cukup untuk memenuhi kebutuhan-kebutuhan nasabah tersebut. Cadangan likuiditas ini bisa dipenuhi oleh perbankan dengan menempatkan giro di Bank Indonesia, memelihara likuiditas aset melalui pinjaman dari perbankan lain.

Menyisihkan aktiva pada sekuritas yang bisa dilego untuk memenuhi keperluan dana perbankan juga dapat mencukupi kebutuhan likuiditas perbankan karena dengan menyisihkan aktiva tersebut melalui sekuritas akan memberikan revenue, dan dengan demikian bank bisa saja mendapatkan revenue yang lebih tinggi daripada kredit (pembiayaan).

Ketentuan ketersediaan likuiditas ini menjadi "buah simalakama" bagi perbankan, di satu sisi perbankan harus menyediakan cadangan dana likuiditas untuk memenuhi kewajibannya yang akan berpengaruh pada profitabilitasnya, dan di sisi lain jika profitabilitas lebih diutamakan dari pada cadangan likuiditas perbankan tersebut akan terkena risiko likuiditas dan meningkatnya biaya. Perbankan tentunya tidak leluasa memaksakan untuk memperoleh profitabilitas yang tinggi karena ada regulasi Bank Indonesia yang harus memenuhi kebutuhan likuiditas ini, dengan regulasi ini perbankan harus memperhatikan ketersediaan cadangan likuiditasnya. Cadangan likuiditas yang ada harus memadai, artinya tidak boleh banyak dan tidak pula sedikit. Jika ketersediaan cadangan likuiditas terlalu kecil dampaknya pada kebutuhan operasional sehari-hari perbankan, dan jika terlalu besar akan berdampak pada tingkat efiseinsi perbankan serta membuat profitabilitasnya menurun. Sementara bagi perbankan syariah lebih sulit untuk mendapatkan dana karena transaksi pembiayaannya tidak berbasis bunga. ${ }^{21}$

${ }^{21}$ Ibid..., hlm. 60. 
Penyebab utama pailit yang melanda kebanyakan perbankan diantaranya adalah karena tidak mampunya mereka memenuhi kebutuhan likuiditasnya, walaupun sebenarnya masih ada faktor lain yang menyebabkan pailitnya perbankan, salah satunya adalah kerugian yang diderita perbankan.

Risiko likuiditas ini diukur dengan instrumen yang cukup kompleks. Ukuran tinggi dan rendahnya risiko likuiditas yang dihadapi perbankan disebabkan oleh banyak faktor, diantaranya adalah:

a. Cermatnya perbankan dalam menyusun cash flow atau fund flow berlandaskan estimasi pinjaman dan estimasi perkembangan dana serta volatility of funds.

b. Tepatnya perbankan dalam menata komposisi dananya, tergolong juga ketersediaan dana-dana non Profit and Loss Sharing.

c. Tersedianya kecukupan aktiva yang bisa ditransformasikan menjadi dana tunai.

d. Kapabilitas perbankan tersebut mewujudkan jalan masuk ke pasar antar bank (untuk bank konvensional) dan pasar uang antar bank berdasarkan prinsip syariah (untuk bank syariah). ${ }^{22}$

\section{Risiko Nilai Tukar Valuta Asing (Foreign Exchange Rate Risk)}

Efek foreign exchange rate risk ini bagi perbankan dilihat dari dua sisi, yaitu saat perbankan pada posisi beli (overbought position/long position), dan saat perbankan ada pada situasi menjual (oversold position/short position). Pada posisi beli risiko nilai tukar valuta asing yang dihadapi perbankan terjadi jika nilai tukar rupiah mengalami kenaikan. Sedangkan pada posisi jual risiko nilai tukar valuta asing yang menghadap perbankan terjadi jika nilai tukar rupiah menurun.

22 Ibid., hlm. 362-363. 
Bahaya yang ditimbulkan dari nilai tukar valuta asing ini bisa diminimalisir oleh perbankan dengan menahan ruang geraknya dalam transaksi valuta asing, bahkan risiko ini bisa dihindari perbankan dengan mengambil posisi square. ${ }^{23}$

Sementara itu perbankan syariah lebih kuat dalam menghadapi risiko nilai tukar valuta asing ini, namun jika perbankan syariah tersebut mengindahkan kepatuhan syariah yang diwajibkan kepadanya, maka perbankan syariah tersebut akan terhindar dari risiko ini dengan alasan:

a. Bank syariah tidak melakukan transaksi arbitrage pada transaksi valuta asingnya, pada prinsipnya bank syariah hanya melakukan transaksi komersial pada transaksi ini.

b. Pertukaran valuta asing yang dilayani oleh bank syariah hanya secara kontan.

c. Short selling tidak diperkenankan dan tidak diberi ruang dalam bertransaksi di bank syariah.

d. Bank syariah tidak melakukan pergantian valuta asing tanpa pengalihan (non delivery trading).

\section{Risiko Operasional (Operational Risk)}

Risiko operasional menurut Komite Basel muncul karena lemahnya pengawasan internal dan lemahnya sistem informasi yang mengakibatkan munculnya kerugian yang tidak diharapkan bagi suatu perbankan. Philip H. Martin lebih jauh menungkapkan bahwa risiko operasional ini muncul karena human error, kegagalan sistem dan kesalahan prosedur serta lemahnya kontrol. ${ }^{24}$ Ghulam Ahmad Yusuf juga memberikan definisi yang hampir mirip dengan apa yang dikemukakan oleh Philip H. Martin, menurut dia risiko

\footnotetext{
${ }^{23}$ Square maksudnya yaitu sama atau seimbang. Dikutip dari Peter Salim, Salim Ninth Collegiate English-Indonesian Dictionary (Jakarta: Modern English Press, 2000), hlm. 1432.

24 Philip H Martin, Operational Risk Management, Speech, presented to the 4 th Islamic banking and Finance Forum, Bahrain, Desember 1997.
} 
operasional muncul kegagalan proses internal perbankan, human error, dan ada juga karena faktor eksternal perbankan yang menyebabkan risiko operasional ini muncul. ${ }^{25}$

Dari beberapa definisi di atas kita temukan beberapa faktor yang berhubungan dengan risiko operasional, diantaranya adalah: (1) sistem informasi, (2) supervisi dari dalam, (3) kelalaian personal; (4) kehampaan struktur; dan (5) kekurangan proses dan pengawasan.

\section{Risiko Modal (Capital Risk)}

Modal berfungsi sebagai pelindung dari kerugian yang mungkin terjadi di perbankan bagi para penyimpan dananya. Jumlah modal yang dibutuhkan untuk melindungi para penyimpan dana ini dilihat dari sisi kualitas dan risiko aset perbankan.

Secara umum aset perbankan dikelompokkan pada aktiva yang terkena efek risiko dan aktiva yang sedikit terkena efek risiko. Aktiva yang terkena efek risiko adalah aset perbankan pada investasi dan pembiayaannya yang tidak dijamin oleh pemerintah. Dan aktiva yang sedikit terkena efek risiko adalah kebalikan dari aset berisiko, yaitu aset pada sekuritas dan investasi yang digaransi oleh pemerintah.

Risiko modal secara umum memperlihatkan tingkat leverage ${ }^{26}$ yang dimanfaatkan oleh perbankan. Risiko modal tidak berhubungan erat dengan kualitas aktiva perbankan. Bagi perbankan yang menginvestasikan dananya untuk membiayai aktiva yang berisiko penting sekali mempunyai penyangga modal yang solid sebagai penopang jika kemampuan masing-masing aktiva tak berjalan sebagaimana mestinya. Kecukupan kapital perbankan juga berfungsi sebagai menopang risiko likuiditas. Agar bahaya yang muncul melalui risiko

\footnotetext{
${ }^{25}$ Ghulam Husain Yusuf, Integrated Operational Risk Managemenr, disampaikan pada konferensi bank Islam internasional pada tahun 2003.

${ }^{26}$ Leverage atau capital gearing (pengungkit modal). Dikutip dari Christopher Pass dan Bryan Lones, Collins Kamus Lengkap Ekonomi, hlm. 67.
} 
ini tidak ditanggung sepenuhnya oleh perbankan, maka manajemen perbankan harus mengalihkan risiko-risiko ini ke asuransi dan menerapkan pengawasan yang ketat untuk menghindari kerugian-kerugian. ${ }^{27}$

\section{Risiko Pasar (Market Risk)}

Risiko pasar merupakan risiko yang memunculkan kerugian di posisi portofolio trading on dan off balance sheet (di neraca dan rekening administrasi). Risiko ini muncul karena adanya perubahan harga pasar di asset dan liabilities. Fluktuasi harga ini terjadi karena akibat perubahan beberapa faktor pasar. Maksud faktor pasar disini yaitu derajat suku bunga perbankan, kurs mata uang asing, harga saham di pasaran, sekuritas dan harga komoditi.

Menurut Ezra Zask risiko pasar ini bisa diukur dengan Value At Risk (VAR). Value at risk (VAR) adalah probabilitas berbasis metrik untuk mengukur aset risiko pasar dan portofolio. VAR sering digunakan sebagai pendekatan dari "maximum reasonable loss" terhadap time horizon. VAR cukup dikenal luas di kalangan bankir komersial, dealer derivatif, dan manajer risiko treasury perusahaan; karena memudahkan interpretasi pada pengukuran risiko serta konsisten mencegah risiko di setiap instrumen keuangan.

VAR adalah statistik yang merangkum paparan aset atau portofolio terhadap risiko pasar. VAR memungkinkan manajer mengukur dan mengungkapkan risiko seperti dalam pernyataan: "kita tidak mengharapkan kerugian melebihi 10 persen dari nilai aktiva bersih dana pada lebih dari satu dari dua puluh kuartal berikutnya". 28

Teknik penghitungan VAR memanfaatkan kaidah kronologis, kaidah analisis, dan ilustrasi Monte Carlo. Kaidah kronologis memanfaatkan pola

${ }^{27} \mathrm{Ibid} \ldots . .$, hlm. 60-62

28 Ezra Zask (editor), Global Investment Risk Managemenet: Protecting International portfolios against currency, interest rate, equity, and commodity risk (New York: McGraw-Hill, 2000), hlm. 187-189. 
tertentu untuk penaksiran VAR, sedangkan VAR Monte Carlo memanfaatkan ilustrasi dan simulasi untuk kalkulasi VAR-nya. ${ }^{29}$

\section{Risiko Tingkat Bunga (Interest Rate Risk)}

Risiko tingkat bunga ini tidak akan terjadi di perbankan syariah karena transaksi-transaksi yang terdapat di bank ini tidak ada yang berbasis bunga ${ }^{30}$ melainkan berbasis bagi hasil, namun sebagai komparasi risiko dengan perbankan konvensional, maka pada tulisan ini risiko tingkat bunga tetap penulis uraikan.

Harga nominal uang dalam pasar perbankan konvensional diukur dengan suku bunga, dan bunga berfluktuasi karena dia beriringan dengan inflasi. Keuntungan atau return on networth (RONW) yang ada di bank konvensional diputuskan oleh net interest margin (NIM) dan hal itu terkait pada penyortiran konstruksi aset $^{31}$ dan liabilitasnya ${ }^{32}$ karena faktor interest rate sensitivity.

Risiko tingkat bunga yaitu risiko bahwa nilai pasar akan mengalami penurunan karena kenaikan suku bunga. Gejala ini merupakan akibat

${ }_{29}$ Mamduh M. Hanafi, Manajemen Risiko, edisi kedua, cetakan pertama (Yogyakarta: STIM YKPN, 2009), hlm. 149.

${ }^{30}$ Latifa M. Al-Goud dan Mervy K Lewis, Perbankan Syari'ah: Prinsip, Praktik, diterjemahkan oleh Burhan Wirasubrata (Jakarta: PT Serambi Ilmu Semesta, 2003, hlm. 11

${ }^{31}$ Manajemen aset adalah istilah yang digunakan untuk menerangkan alokasi dana diantara berbagai alternatif investasi yang ada. Di kutip dari Edward W. Reed dan Edward K. Giil, Bank Umum, diterjemahkan oleh St. Dianjung, edisi keempat (Jakarta: Bumi Aksara, 1995), 94-95. Lihat juga James C. Van Horne dan John M. Wachowicz, Prinsip-Prinsip Manajemen Keuangan, diterjemahkan oleh Heru Sutojo, buku ke-2 (Jakarta: Salemba Empat, 1998), hlm. 368.

${ }^{32}$ Dalam pengertian luas, manajemen liabilitis terdiri dari kegiatan yang menyangkut pencarian dana dari penabung dan kreditor lainnya dan menentukan perbandingan dana yang tepat bagi suatu bank tertentu. Dalam pengertian yang lebih sempit, manajemen liabilitis dikenal sebagai kegiatan yang berkaitan dengan melengkapi kebutuhan likuiditas dengan secara aktif mencari dana pinjaman kalau diperlukan. Manajemen liabilitis mengharuskan bank untuk mempertimbangkan risiko tambahan karena perbedaan antara biaya mencari dana dan hasil yang dapat diperoleh kalau dana tersebut ditanamkan pada kredit dan surat berharga. Dengan demikian hubungan antara manajemen aset dan manajemen liabilitis penting dalam menentukan kemampuan bank untuk meraih laba. Ibid..., hlm. 120. 
pengaruh suku bunga menurut perjanjian ketika obligasi ${ }^{33}$ tersebut ditempatkan dan kebebasan relatif suku bunga pasar untuk bergerak naik turun. Obligasi pemerintah federal misalnya, yang dikeluarkan pada tahun 1960 dengan bunga 3,5 persen dan jatuh tempo pada tahun 1998 kehilangan nilai yang cukup besar dalam tahun-tahun belakangan karena kenaikan suku bunga setelah tahun 1960. Biasanya, semakin jatuh tempo suatu instrumen kredit, semakin besar risiko tingkat bunga. ${ }^{34}$

\section{Risiko Pembiayaan Bank Syariah}

Dari sekian banyak risiko yang terdapat pada produk-produk pembiayaan bank syariah yang harus dilakukan perbankan syariah adalah meminimalkan risiko-risiko yang ada. Risiko-risiko pembiayaan ini bisa diminimalkan dengan risk management secara efektif dan efisien. Agar risk management ini efektif dan efisien langkah pertama yang dilakukan perbankan syariah adalah screeening kepada calon-calon nasabah pembiayaan. Bahkan jika pembiayaan sudah dicairkanpun bank syariah masih harus mengendalikan risiko pembiayaannya dengan memberikan perlakukan (treatment) berdasarkan dengan personalitas nasabah dan bisnis yang diberikan pembiayaan. ${ }^{35}$

\section{a. Risiko Pembiayaan Murabahah}

Pembiayaan murabahah ${ }^{36}$ sebenarnya adalah pembiayaan yang paling banyak mendapat animo nasabah bank syariah Indonesia dan luar negeri. Namun, walaupun produk ini adalah produk yang banyak

${ }^{33}$ Bond (obligasi) merupakan pengakuan utang pihak yang mengeluarkan kepada pihak yang membeli (investor) atau suatu perjanjian tertulis untuk membayar sejumlah uang tertentu pada tanggal tertentu di masa yang akan datang dan tambahan uang berupa keuntungan yang didapat dari bagi hasil (mudharabah). Dikutip dari Ivan Rahmawan, Kamus Istilah Akuntansi Syariah (Yogyakarta: Pilar Media, 2005), hlm. 299.

${ }^{34}$ Edward W. Reed dan Edward K. Giil, Bank Umum...., hlm. 322.

${ }^{35}$ Muhammad, Manajemen Bank Syariah, hlm. 365.

${ }^{36}$ Murabahah sebagaimana yang digunakan dalam bank syariah, prinsipnya didasarkan pada dua elemen pokok, yaitu harga beli serta biaya yang terkait, serta kesepakatan atas laba (mark up). Dikutip dari Abdullah Saeed, Islamic Banking and Interest: a Study of Prohibition of riba and Its Contemporary Interpretation, vol. II (Leiden: Brill, 1996), hlm. 55. 
diminati oleh nasabah bank syariah ternyata produk ini juga berisiko. Dari sisi nasabah produk ini banyak diminati karena sistemnya sederhana dan banyak memberikan manfaat kepada nasabah, sementara dari sisi perbankan syariah produk murabahah ini penanganan administrasinya lebih simpel dan sederhana.

Menurut Syafi'i Antonio beberapa risiko yang terdapat pada pembiayaan murabahah ini adalah:

1) Kelalaian yang diperbuat oleh debitur (default). Contohnya adalah nasabah secara sengaja tidak mau mengangsur angsuran pembiayaan yang diwajibkan kepadanya.

2) Instabilitas harga komparatif, yaitu kenaikan harga komoditas yang telah dibelikan bank syariah untuk nasabah pembiayaannya. Jika pembiayaan ini sudah ditandangani akadnya, maka bank syariah tidak bisa mengganti harga jual barang kepada nasabah pembiayaannya, dengan demikian risiko fluktuasi harga ini akan ditanggung oleh bank syariah.

3) Penolakan nasabah terhadap komoditas barang yang dikirimkan kepadanya. Nasabah mempunyai hak menolak barang yang dikirimkan kepadanya dengan berbagai alasan. Rusaknya barang yang dikirim dalam perjalanan dan barang yang diantar berbeda dengan spefisikasi yang diinginkan nasabah adalah beberapa alasan yang menyebabkan penolakan tersebut.

4) Barang yang djadikan sebagai objek pembiayaan dijual oleh nasabah. Karena murabahah adalah perjanjian dagang dengan hutang, maka setelah akad ditandatangani oleh nasabah pembiayaan; kepemilikan barang objek akad tersebut berpindah juga kepemilikannya kepada nasabah pembiayaan. Dan ketika komoditas tersebut telah menjadi kepunyaan nasabah, tentunya nasabah punya hak berbuat semaunya terhadap barang yang 
dimilikinya, termasuk melegonya. Jika hal ini terjadi bank syariah akan menghadapi risiko default yang semakin besar. ${ }^{37}$

b. Risiko Pembiayaan Ijarah

Akad ijarah berbeda dengan akad murabahah, pada akad ijarah yang ditransaksikan adalah pengalihan utilitas dari suatu komoditas dengan upah sewa tanpa berpindahnya kewenangan kepemilikan komoditas barang. ${ }^{38}$ Namun, barang tersebut bisa juga berpindah kepemilikannya jika akad yang disepakati adalah ijarah muntahiya bi at-tamlik (IMBT).

Keuntungan yang diperoleh bank syariah dari akad ijarah ini adalah profit dalam bentuk sewa dan kembalinya uang pokok. Sedangkan menurut Syafi'i Antonio risiko yang ada pada akad ijarah ini yaitu:

1) Nasabah secara sengaja tidak berminat mengangsur cicilan pembiayaan yang diwajibkan kepadanya (default).

2) Rusaknya aset ijarah. Ketika aset ijarah mengalami kerusakan, maka biaya pemeliharaan aset tersebut akan bertambah besar, apalagi jika disepakati dalam akad bahwa pemeliharaan aset menjadi tanggung jawab bank syariah, tentunya bank syariah akan menanggung risiko ini.

3) Nasabah mundur dan berhenti dari ikatan akad ketika akad sedang berjalan dam tidak mau membeli aset objek akad. Akibatnya bagi bank syariah adalah bank harus menghitung kembali keuntungan yang diperoleh ketika akad berjalan dan mengembalikan sebagiannya kepada nasabah. ${ }^{39}$

37 Muhamamd Syafi'i Antonio, Bank Syari'ah Wacana Ulama dan Cendekiawan (Jakarta: Tazkia Institute dan Bank Indonesia, 1999), hlm. 127-128.

${ }^{38}$ Sunarto Zulkifli, Panduan Praktis Transaksi Perbankan Syari'ah, cet ke-II, (Jakarta: Zikrul Hakim: 2004), hlm. 42.

${ }^{39}$ Muhammad Syafi'i Antonio, Bank Syari'ah: Dari Teori ke Praktek (Jakarta: Gema Insani Press, 2001), hlm. 119. 
c. Risiko Pembiayaan Salam dan Istishna'

Akad salam dan istishna' adalah akad yang mempunyai keunikan tersendiri di bank syariah karena pembayaran akadnya dilakukan di muka sedangkan penyerahan barangnya dilakukan secara tangguh (tidak langsung diserahkan). ${ }^{40}$ Kedua akad ini pun juga tidak bebas risiko karena akan menghadapi risiko:

1) Karena barang yang diserahkan dilakukan secara tangguh, maka risiko gagalnya barang diserahkan (non deliverable risk) bisa saja muncul. Untuk mengantisipasi kemungkinan munculnya risiko ini, bank syariah bisa melakukan penetapan kovenan rasio kolateral sebesar 220\% (100\% lebih tinggi dibandingkan dengan rasio standar sebesar $120 \%)$.

2) Risiko jatuhnya harga barang (price drop risk) yang menjadi objek akad. Risiko ini bisa diantisipasi bank syariah dengan mematok bahwa suatu pembiayaan hanya dilakukan berdasarkan akad atau orderan yang telah ditetapkan nilainya. ${ }^{41}$

d. Risiko Pembiayaan Mudharabah dan Musyarakah

Risiko-risiko yang kemungkinan muncul dalam pembiayaan mudharabah dan musyarakah ini adalah:

1) Side streaming; debitur memanfaatkan pinjaman yang diberikan tidak sinkron dengan yang diperjanjikan di dalam akad. Misalnya akad yang ditandangani adalah akad mudharabah modal usaha, ternyata pada aplikasinya nasabah menggunakannya untuk

40 Salam adalah akad jual beli barang pesanan antara pembeli dan penjual dengan pembayaran di muka dan pengiriman barang oleh penjual di belakang. Di kutip dari Tim Penyusun Pedoman Akuntansi Perbankan Syariah Indonesia (IAI), Pedoman Akuntansi Perbankan Syariah Indonesia (PAPSI 2003) (Jakarta: Ikatan Akuntansi Indonesia, 2003), hlm. 37 dan 41.

${ }^{41}$ Adiwarman Karim, Bank Islam Analisis Fiqih dan Keuangan, edisi dua (Jakarta: PT Raja Grafindo Persada, 2004), hlm. 245. 
membeli mobil yang tujuannya untuk konsumtif (seharusnya akad murabahah).

2) Kelalaian dan kesalahan yang sengaja dilakukan oleh nasabah.

3) Tidak jujurnya nasabah dengan keuntungan yang diperolehnya. Misalnya keuntungan yang diperoleh nasabah dari usaha yang dimodali bank syariah dengan akad mudharabah perbulannya adalah Rp 2 juta, namun yang dilaporkan kepada bank syariah hanya Rp 1 juta. ${ }^{42}$

e. Risiko Pembiayaan Rahn dan Hiwalah

Pembiayaan Rahn dan hiwalah adalah jasa keuangan yang ditawarkan oleh perbankan syariah. Produk pembiayaan rahn ini akan menghadapi risiko:

1) Risiko nasabah tidak membayar hutangnya (wanprestasi).

2) Risiko turunnya harga nilai aset (barang) yang ditahan dan risiko kemungkinan rusaknya aset yang ditahan.

Sedangkan pada produk pembiayaan hiwalah risiko yang terdapat pada produk ini adalah kemungkinan nasabah berbuat curang dengan memberikan invoice palsu dan tidak menepati janjinya dalam menunaikan kewajiban (hiwalah)nya ke bank syariah. ${ }^{43}$

\section{Kesimpulan}

Secara umum risiko yang dihadapi bank syariah hampir mirip dengan risiko yang terdapat di bank konvensional, hanya saja bedanya di bank syariah tidak terdapat risiko suku bunga karena transaksi yang ada di bank syariah tidak berbasis suku bunga sebagaimana bank konvensional. Selain itu, risiko

42 Muhammad Syafi'i Antonio, Bank Syariah: Bagi Bankir dan Praktisi Keuangan (t.tp: t.np, 1420 H/1999 M), hlm. 148 dan 153.

${ }^{43} \mathrm{Ibid} . . .$, hlm. 195 dan 198. 
yang dihadapi bank syariah terbagi kepada risiko berdasarkan prinsip pembiayaan yang disalurkan oleh bank syariah.

\section{DAFTAR PUSTAKA}

Antonio, Muhamamd Syafi'i, Bank Syari'ah Wacana Ulama dan Cendekiawan, Jakarta: Tazkia Institute dan Bank Indonesia, 1999. Bank Syari'ah: Dari Teori ke Praktek, Jakarta: Gema Insani Press, 2001. H/1999 M.

Arifin, Zainul, Dasar-dasar Manajemen Bank Syari'ah, Jakarta: Pustaka Alvabet, 2005.

Arnold, Beth dan Paul de Lange, "Enron: an Examination of Agency Problems", Critical Perspectives on Accounting, 15 (6), 2004, hlm. 751-765

Aznan, Syed Jaafar, Islamic Financial Industry: Risk Management, Regulation and Supervision, disampaikan pada disampaikan pada konferensi bank Islam internasional pada tahun 2003.

Bitner, Jhon dan Robert A. Goddard, Asset Liability Management: A Guide to The Future Beyond GAP, New York: John Wiley dan Sons, 1992.

Hanafi, Mamduh M., Manajemen Risiko, edisi kedua, cetakan pertama, Yogyakarta: STIM YKPN, 2009.

Herijanto, Hendy, Selamatkan Perbankan Demi Perekonomian Indonesia, Jakarta: Expose PT Mizan Publika, 2013.

Horne, James C. Van dan John M. Wachowicz, Prinsip-Prinsip Manajemen Keuangan, diterjemahkan oleh Heru Sutojo, buku ke-2, Jakarta: Salemba Empat, 1998.

Idroes, Ferry N., Manajemen Risiko Perbankan: Pemahaman Pendekatan 3 Pilar Kesepakatan Basel II Terkait Aplikasi Regulasi dan Pelaksanaannya di Indonesia, Jakarta: Rajawali Pers, 2008.

Iqbal, Anjum, “Liquidity Risk Management: A Comparative Study between Conventional and Islamic Banks of Pakistan", Global Journal of Management and Business Research, Vol. 12, Edisi 5, versi 1.0, Maret 2012.

Karim, Adiwarman, Bank Islam Analisis Fiqih dan Keuangan, edisi dua, Jakarta: PT Raja Grafindo Persada, 2004.

Lewis, Mervyn K. dan Latifa Algoud, Perbankan Syari'ah: Prinsip, Praktik, diterjemahkan oleh Burhan Wirasubrata, Jakarta: PT Serambi Ilmu Semesta, 2003.

Martin, Philip H, Operational Risk Management, Speech, presented to the 4 th Islamic banking and Finance Forum, Bahrain, Desember 1997. 
Muhammad, Dasar-dasar Keuangan Islami, Yogyakarta: Ekonisia, 2004. Manajemen Bank Syariah, edisi revisi, Yogyakarta: (UPP) AMP YKPN), 2005.

Manajemen Pembiayaan Mudharabah di Bank Syariah, Jakarta: Rajawali, 2008.

Pass, Christopher dan Bryan Lones, Collins Kamus Lengkap Ekonomi, edisi kedua, diterjemahkan oleh Tumpul Rumapea dan Posman Haloho, Jakarta: Erlangga, 1994.

Perwataatmadja, Karnaen dkk, Bank Dan Asuransi Islam di Indonesia, editor Wirdyaningsih, Jakarta: Kencana, 2005.

Rahmawan, Ivan, Kamus Istilah Akuntansi Syariah, Yogyakarta: Pilar Media, 2005.

Reed, Edward W. dan Edward K. Giil, Bank Umum, diterjemahkan oleh St. Dianjung, edisi keempat, Jakarta: Bumi Aksara, 1995.

Saeed, Abdullah, Islamic Banking and Interest: a Study of Prohibition of riba and Its Contemporary Interpretation, vol. II, Leiden: Brill, 1996.

Salim, Peter, Salim Ninth Collegiate English-Indonesian Dictionary, Jakarta: Modern English Press, 2000.

Sarker, Md. Abdul Awwal, "Islamic Business Contracts, Agency Problem and The Theory of The Islamic Firm", International Journal of Islamic Financial Services, Vol. 1, No. 2.

Tim Penyusun Pedoman Akuntansi Perbankan Syariah Indonesia (IAI), Pedoman Akuntansi Perbankan Syariah Indonesia (PAPSI 2003), Jakarta: Ikatan Akuntansi Indonesia, 2003.

Usman, Rachmadi, Aspek Hukum Perbankan Syariah di Indonesia, Jakarta: Sinar Grafika, 2012.

Yusuf, Ghulam Husain, Integrated Operational Risk Managemenr, disampaikan pada konferensi bank Islam internasional pada tahun 2003.

Zask, Ezra (editor), Global Investment Risk Managemenet: Protecting International portfolios against currency, interest rate, equity, and commodity risk, New York: McGraw-Hill, 2000.

Zulkifli, Sunarto, Panduan Praktis Transaksi Perbankan Syari'ah, cet ke-II, Jakarta: Zikrul Hakim: 2004. 